\title{
9
}

\section{Reproducing Socio-Spatial Unevenness Through the Institutional Logic of Dual Housing Policies in Hungary}

\section{Zsuzsanna Pósfai and Csaba Jelinek}

\section{Introduction}

The increasing role of finance is central to the current transformations of capitalism, with a globally growing amount of money looking for profitable forms of investment (Fernandez and Aalbers 2016). This search for a financial fix systematically channels money towards the built environment-and in certain contexts specifically towards housing (Aalbers 2017). In order to grasp this inherently spatial nature of financialisation (Sokol 2013), we build on the notion of uneven development. Recent work in the field of economic geography aiming to

\section{Z. Pósfai $(\bowtie)$}

Periféria Policy and Research Centre, Budapest, Hungary

C. Jelinek

Centre for Economic and Regional Studies (CERS-HAS), Hungarian Academy of Sciences, Budapest, Hungary

C. Jelinek

Central European University, Budapest, Hungary

(C) The Author(s) 2019

T. Lang and F. Görmar (eds.), Regional and Local Development 
reconceptualise this approach has put specific emphasis on understanding the concrete institutional mechanisms that produce socio-spatial unevenness on various scales (Dunford and Liu 2017; Hudson 2016; Peck 2016). Common to these propositions is the claim that capitalism should be understood as one interconnected and hierarchically structured system; however, empirical emphasis should be put on the intermediary scales of institutional infrastructures, policy developments, firm strategies and subnational spatial patterns in order to understand the mechanisms producing uneven development in a such a varied way. Thus, we approach the issue of spatial polarisation through the perspective of uneven development, since we believe this notion gives us more scope to understand the production of socio-spatial inequality as a multiscalar and non-linear process. Furthermore, we work with this notion because we seek to link our analysis to a body of literature analysing the spatiality of capitalism.

In this chapter, we analyse the development of Hungarian housing policies since the turn of the millennium, investigating how policy interventions reinforce and support the rolling out of uneven socio-spatial development in the field of housing. Housing is an important spatial fix under financial capitalism everywhere in the world; however, the concrete ways in which this is articulated vary across different institutional contexts. We investigate the Hungarian institutional context as situated in a broader, European and global set of hierarchical, interdependent connections. We believe this approach provides useful insights for understanding how policy interventions can channel macroeconomic pressures in a semiperipheral context of the European (and global) economy.

We will not only highlight the role of housing-as-investment, but will also link seemingly more progressive and socially sensitive housing policies to the broader frame of housing under a financialised regime of accumulation. Analysing this branch of policies provides insights into how the state manages spatially concentrated social deprivation in a country with a very minimal share of social/public housing-which is the case for the majority of the Central and Eastern European member states, as well as most countries outside the European Union. 
The starting point of our argument is that Hungarian housing policies are essentially dualised. By dualisation we mean that in a generally fragmented policy arena-since 1989 there has never been a coherent housing policy in Hungary-most individual policy measures intervening in the field of housing either target the relatively well-off upper classes (although claiming to be general in their scope), or very marginalised social groups. The former aim to integrate middle-class households in a financialised housing regime based on individual ownership and debt, while the latter aim to manage and contain spatially concentrated manifestations of housing poverty. We will call these two approaches the liberal and social facets of housing policies. While these policies at the "top" and at the "bottom" of the housing sector are seemingly separate interventions and are never connected narratively by government actors, in our view they are functionally interconnected and should thus be analysed in a holistic manner. This functional interconnection is the most evident when we employ the framework of uneven development. Accepting the claim that global capitalism systematically produces socio-spatial polarisation, we will show how this happens in the field of housing in Hungary through the mediation of certain institutional logics. While dominant (neoliberal) approaches to housing policy are usually planned and executed without reference to their spatial dimension and are claimed to benefit households in a general way, we will demonstrate how they actually reproduce socio-spatial unevenness.

Even though our argument will be rooted in different empirical processes, the main goal of this chapter is to reconstruct the institutional logics behind these spatialities, and not to provide an exhaustive picture of all the empirical aspects of capitalist uneven development in the domain of housing in Hungary.

This study can also provide valuable insights into more general questions about the spatiality of policy intervention in housing under the current wave of financial capitalism. The two modes of intervention which we study adhere to general directions of housing policy development throughout Europe. The dominant model for housing provision in all European countries (and also globally) is to push for indebtedness-based individual homeownership, while marginalised 
social groups living in an increasingly residualised social housing sector are targeted by narrowly focused and often controlling public interventions (Czischke 2009). Furthermore, the vulnerable housing finance system that has developed in Hungary since the late 1990s, based on an externally dependent banking sector, short-term financial resources and individual mortgages (Raviv 2008) is quite typical for all Central and Eastern European countries-although historical and institutional differences are crucial (Bohle 2017). Similarly, the significant role of EU funds in targeting those living in deprived housing conditions is also quite typical for the region. ${ }^{1}$ Thus, our analysis can contribute to a better understanding of variations in Central and Eastern European housing policy, while proposing a more systemic framework of macroeconomic processes driving these contextually specific policy interventions.

The empirical basis of this chapter is anchored in two lots of doctoral fieldwork. Pósfai has been focusing on core-periphery relations embedded in the strategies of housing market actors in Hungary (within the framework of the Marie Curie ITN "RegPol ${ }^{2}$ - Socio-economic and Political Responses to Regional Polarisation in Central and Eastern Europe"), while Jelinek has been working on the history of urban rehabilitations in Hungary from the 1970s (at the Department for Sociology and Social Anthropology of the Central European University). Both researches deployed a mixed methodology: qualitative insights from interviews with the main stakeholders and ethnographic observations of certain key projects were coupled with macrostatistical analyses and with the scrutiny of policy documents and plans. Since the main aim of this chapter is to reconstruct certain institutional logics behind the general trend of uneven development, it will mainly be the interviews conducted during these researches that provide the empirical backbone of our argument. While our understanding of the liberal and social facets of housing policies in Hungary were also informed by quantitative data and document analyses, we will restrict ourselves to the presentation of our most important qualitative findings (occasionally referencing some of our own prior publications using related quantitative data) due to the limited space we have. 
In this chapter we will thus argue that state intervention in the Hungarian housing market is dualistic, with seemingly disconnected policy instruments targeting two ends of the housing spectrum. While the dominant trajectory of neoliberal housing policy in Hungary is to promote indebtedness-based individual homeownership, spatially targeted, small-scale and localised interventions in the public housing stock are meant to correct the exclusionary processes produced by this trajectory, but their effectiveness is highly questionable. State intervention thus reinforces spatial patterns of capitalist development and deepens unevenness of the housing market, while seemingly applying "patches" to the areas that are the most obvious losers of this process.

\section{The Liberal Facet of Housing Policies ${ }^{2}$}

The declared aim of Hungarian housing policy is to promote individual homeownership (Misetics 2017). This has been the very clear political preference of all governments ever since the 1980s, and in the current conservative government this ideology of homeownership is reputed to be unquestionable at the level of the prime minister himself. According to a high-ranking official in the public administration, "the definition of Hungarian housing policy is actually just different forms of subsidies to homeownership". 3 This conservative political preference is of course well in line with and not independent of broader economic processes and general tendencies of liberal housing policies across Europe, which all promote similar aims (Fernandez and Aalbers 2016). Although in this sense the Hungarian housing regime follows the common European (and global) trajectory of housing financialisation described by Fernandez and Aalbers (2016), the concrete ways in which capital is channelled into the housing market are determined by the specific instruments employed.

In the following section we will explore the socio-spatial effects of two of the most important housing policy instruments of the past decades, which were implemented in order to serve the political aim of access to homeownership: (1) a non-refundable state subsidy allocated to families mainly based on the number of children they have 
(previously called szocpol, now called CSOK), and (2) state-subsidised mortgages. These two instruments have shifted in their significance visà-vis each other, and also in their target groups and budgetary weight, but in essence have not changed. Both instruments declaratively serve access to individual homeownership, which is the dominant form of tenure in Hungary (owner occupancy is currently around 90\%). Given the political priority of this aim, these instruments are also the ones that receive the most budgetary support. In 2005, for instance, budgetary resources supporting access to homeownership represented nearly $95 \%$ of all public spending for housing purposes, and this proportion was never less than $85 \%$ during the whole pre-crisis decade (Misetics 2013,52 ). They are articulations of a liberal housing policy at the service of economic actors in the field, and favouring those households that have significant savings, while also pushing for the privatisation of housing-related risks through individual indebtedness (Crouch 2009). We will show how these instruments, in spite of being presented as a generalised housing support to the whole of Hungarian society, framed along the lines of demographics and conservative family politics, are actually channelling resources towards the middle classes (to the detriment of lower social classes), and are also contributing to increasing spatial unevenness.

The first instrument of the liberal facet of housing policy is a state subsidy supporting access to homeownership, which has been in place since 1994 (with a few years' gap after 2009). Concrete allocation criteria have changed throughout the years, but it has always been framed as a demographic/social policy tool (for a long time it was also called the "social policy benefit"—szociálpolitikai kedvezmény, nicknamed szocpol) allocated according to the number of children in a family. Since the early 2000s this has been complemented by the second main instrument of access to homeownership: mortgage lending. Mortgage lending was kick-started by the introduction of a statesubsidised mortgage programme in 2001, and then expanded very rapidly until 2010: there was a 35-fold increase in the stock of outstanding mortgages between 2000 and 2010 (Hegedüs and Somogyi 2016). The subsidised mortgage programme was stopped in 2004, but by then the liberalisation of the banking sector made the widespread 
distribution of cheap mortgages denominated in foreign currencies possible (Pósfai et al. 2018).

Both "strands" are highly publicised housing policy initiatives, but are rarely linked in public discourse. However, they are mutually dependent on each other: the non-refundable housing allocation distributed on a "demographic" basis (szocpol) is rarely sufficient in itself for acquiring property, and its efficiency is thus largely dependent on the availability of mortgages (or significant household savings). On the other hand, many households would not have the necessary capital for their downpayment for a mortgage without the non-refundable housing allocation. Thus, the latter is practically often used as a tool for capitalising otherwise not creditworthy households. This complementarity is well observed in the current situation, where a new wave of housing subsidies (this time called the "allocation for the home creation of families"; családok otthonteremtési kedvezménye, or CSOK) was introduced at the beginning of 2016 in a context of historically low interest rates, and coupled with an impressive decrease (from 27 to 5\%) of VAT on new housing construction. Currently, 80\% of households receiving CSOK also have a mortgage: thus, although the family-based housing subsidy is framed as an instrument supporting deserving, employed, childbearing Hungarian families, it actually becomes a tool catalysing further household indebtedness. ${ }^{4}$ Furthermore, the current housing subsidy (CSOK) has a few notable changes compared to its predecessor (szocpol) that orient it even more towards new construction and towards households of higher social status. The latter can be achieved by cancelling the maximum value of real estate the subsidy can be used for, as well as through stricter employment and income criteria for the beneficiaries. As a result, the circle of households who can access this subsidy is narrower. ${ }^{5}$ A project done by an NGO working in a poor and segregated Roma community demonstrated how families living in housing poverty have no possibility to benefit from this housing allocation. ${ }^{6}$

In the liberal facet of Hungarian housing policy, the government claims that it does not wish to intervene in or "distort" market processes, ${ }^{7}$ and strongly relies on an agenda of privatising risks, costs and also operative management of housing provision. This privatisation of housing provision goes two ways: primarily, it means a strong reliance 
on individual resources of households (the notion of "self-reliance" or "self-care"-öngondoskodás is absolutely central in government communication) through intergenerational transfers, private individual construction and individual indebtedness. ${ }^{8}$ The other aspect of privatised housing provision is to economic actors. The role of economic actors, mainly banks involved in housing finance, is crucial from the conception to the implementation of housing policy. Since the above-described instruments are individually allocated financial transfers, financial institutions have become front-desk operators of housing policy in Hungary. This means that their role is crucial in consultation processes leading up to the definition of policies, and also that they are the institutions managing the implementation of housing policy. This strategy of privatising implementation is particularly important for Hungarian decisionmakers, who-in line with the liberal idea of self-reliance-do not wish to sustain a public apparatus in this sector. ${ }^{9}$

This neoliberal housing policy, which dominantly relies on a creditbased access to homeownership, is inherently polarising both socially and spatially. A credit-based housing finance system necessarily benefits households that have a higher wealth and income status. In their case a mortgage can act as an effective means of leverage in the process of individual wealth accumulation. This becomes particularly important in the context of a society where inheritance and inter-generational transfers play a crucial role in access to housing. Credit lending policies of financial institutions are constructed in a way to favour clients with more reliable economic indicators, thus better-off households will receive credit with much better underwriting criteria. ${ }^{10}$ Policy instruments focusing on subsidising the cost of credit are thus disproportionally channelled to middle-class households (Hegedüs 2006) and to economically more prosperous geographical areas. A housing finance system based on individual credit (and additionally channelling state subsidies into property acquisition without any concern for affordability) will necessarily be translated into house price hikes very quickly. Current house price increases mainly affect core urban housing markets, which are already under pressure, reinforcing existing spatial unevenness. 
The selectivity of credit distribution is also true in a spatial sense; meaning that it is more difficult to secure external financing for housing in smaller or economically worse off localities. The spatial patterns of the Hungarian housing market in the past three decades have largely been determined by the mortgage lending policies of financial institutions. The dominant tendencies can be grasped by the dual, polarising terms of financial overinclusion and redlining (Aalbers 2008). These notions allow us to grasp the dual pattern of homogenisation and differentiation inherent to uneven spatial development. The former is a pattern of including social and geographical entities which were previously excluded from financial services. However, in the mid-and long term, this inclusion also creates the vehicle which allows for the extraction of resources from these more peripheral/marginal spaces and social groups. Consequently, a new wave of spatial (known as redlining) and social exclusion follows, as a strategy of risk management for the stakeholders involved in the process. The geography of overinclusion and redlining largely overlap (Aalbers 2008). The story of Hungarian mortgage lending is well described in this logic. In the period preceding the financial crisis, mortgage lending rapidly rolled out in Hungary as the main tool of access to housing. This was supported by the two main policy instruments we identify as constituting the liberal facet of Hungarian housing policy: family-based housing allocation and the state-subsidised mortgage programme. From 2000 to roughly 2008-2010 ever broader social and spatial segments were included in mortgage lending. The market incentives of financial institutions, the social need generated by the lack of other channels of access to housing, and the progressively relaxed criteria for access to state subsidies reinforced each other in this process. During this period, mortgages were granted to households with weaker repayment capacities, or in localities that later proved to be immobile in terms of housing market activity. When the financial crisis hit Hungary, a social crisis of over-indebtedness, as well as a geography of financial overinclusion emerged (Bohle 2013). 
What we call the geography of financial overinclusion are the areas where housing markets were most direly affected by the financial crisis. These are areas where house prices dropped the most significantly and default on mortgage payments represented a serious social issue. In these areas housing markets are — up until today-dominated by the sale of properties serving as collateral for non-performing mortgages. ${ }^{11}$ Following the crisis, banks in Hungary introduced much stricter redlining policies, excluding certain geographical localities from their mortgage lending. Although this would need further empirical investigation, our initial analysis suggests that the geography of previous financial overinclusion and post-crisis geographies of redlining largely overlap. ${ }^{12}$ This is also a consequence of the fact that redlining lists are (among other things) constructed based on employment and housing transaction statistics.

How does this geography of mortgage lending link up to the housing policy instruments described above? According to data provided by one of the most important banks in Hungary, the housing allocation provided to families (szocpol) was proportionally much more important in villages and smaller cities in the years before the crisis. ${ }^{13}$ Currently, after one and a half years of the "new" type of family housing allocation (CSOK; introduced in early 2016) we can say that the narrower socio-spatial focus of the current subsidy is clear compared to the pre-crisis period: villages are now receiving much less of this allocation, and the main beneficiaries are "intermediary" urban areas that have somewhat lower house prices. ${ }^{14}$

We can broadly identify (mainly based on evidence from interviews conducted with housing market actors in various locations) three typical geographies produced by Hungarian liberal housing policies. On the one hand, the core (most central) areas are the ones where capital (both mortgages and state subsidies) is concentrated in periods of crisis, and which are the primary beneficiaries of re-launching the housing market. The controversy is that these areas would have prospering housing market activity even without any state subsidies. However, since these subsidies are not tied to any income restrictions, nor are they spatially targeted, eligible households often use them in these "core" locations as a supplement to their investment. 
Secondly, the areas which are the most affected by government housing policies and where non-refundable subsidies used to access homeownership have the strongest effect are the spaces which we coin as the "peripheries of cores". Concretely, these mean the immediate agglomeration area of Budapest, or major secondary cities and their immediate outskirts. These are places which are not excluded by banks' redlining policies, and where households can strike a manageable balance between housing affordability and access to employment. In these areas, the proportion of households benefiting from the non-refundable housing subsidies is extremely high (in some places $80-90 \%$ of all transactions). Often, these households would not have sufficient savings to acquire a mortgage without the state subsidy. Thus, liberal housing policies have the most direct effect on these "intermediary" housing markets. Furthermore, these are the spaces where subsequent waves of government housing policy have left their trace in a superimposed way, and which become key areas for housing mobility and geographical mobility as well. For instance, families acquiring property in the suburbs of certain major second-tier cities (e.g. Debrecen) during the mortgage boom of the early 2000s can now often benefit from the new housing allocation in their own trajectory of housing mobility, investing in the centre of the city. Housing markets of specific cities or agglomeration areas (e.g. the immediate eastern suburbs of Budapest) where the majority of housing transactions were previously realised with cheap mortgages (either subsidised or foreign currency mortgages) are also currently being mobilised by the new wave of public subsidies after years of immobility.

The third geography we identify is that of peripheralised housing markets. These are places which may have shown some housing market activity in the most expansive phase of mortgage lending, but which experienced dropping house prices and a completely frozen housing market in recent years. In these areas house prices are so low that the family-based housing subsidy can be sufficient in itself for buying property, often pushing non-creditworthy households to buy here. Before the crisis this was a quite widespread practice and led to situations of segregation and blocked mobility (families being trapped in the bad quality housing they could acquire this way), increasing socio-spatial unevenness. Currently, due to stricter rules of access, this usage of the subsidy 
is less common/not possible on a wide scale. Furthermore, within these peripheralised spaces there are also certain localities (most notably small villages of the eastern and southern peripheries) which have been continuously declining since the early 1990s. The spatial marginality produced by structural processes of economic transformation has been reinforced by the above-described processes of the housing market.

Since 2010, the government has introduced a number of measures aimed at handling the social and economic crisis of defaulting mortgages. As a result, access to credit has become much more restricted (both socially and spatially), and the housing market is becoming even more unequal. Having "learned the lesson" that financial overinclusion induces crisis, there was an aggressive political discourse of anti-liberalism and stricter regulation in relation to housing finance between 2010 and 2015. However, it is important to see how this anti-liberalism remains to be a political rhetoric, since the fundamental elements of a financialised housing regime are currently being quite efficiently reconstructed. From 2015 onwards, the previous family-based housing allocation was rebranded as "CSOK" and mortgage lending started to be promoted again. The discourse supporting this new rollout of the same liberal housing finance system is that this time house price increases are supported by economic growth, mortgage lending is prudent and regulated, and the housing market is experiencing a healthy recovery, without any bubbles bursting. All actors are aiming to prove that they will not commit the same "mistake" again. However, looking at the socio-economic reality behind this political narrative shows that it is fragile from several points of view. At the moment housing finance institutions can profitably function while targeting only a more restricted pool of customers. In the meantime, no other, radically different housing finance instruments have been introduced, there is thus an increasing share of Hungarian society who simply do not have access to any channels of housing finance. This will likely result in increasing social pressure generated from below, which will meet the financial institutions' incentive for market expansion once their current market is saturated. In the absence of other policy measures, this could lead to similar patterns of financial overinclusion as before the crisis (if current regulations are relaxed in response to these pressures). A further limitation is that household savings currently being 
channelled into housing will diminish if there is no significant increase in wage levels (which could lead to increased savings). This, along with the persistent lack of long-term financial resources in the Hungarian banking sector (Gál 2014), means that in the long term, financial resources for this model of privatised housing provision risk drying up-both on a household and on a corporate scale. Thus, although the declared objectives of these liberal housing policy instruments are demographic and economic growth, we can see how the socio-spatial unevenness produced as a consequence is not incidental, but incremental to this policy approach to housing.

\section{The Social Facet of Housing Policy}

Even though the dominant, albeit not necessarily explicit principle of Hungarian housing policy is a primarily liberal one, it has always been coupled with a social facet, which supposedly had to manage the negative consequences of uneven development. From a spatial perspective the function of the social facet has been to contain the tensions in those marginal and peripheral spaces, which are never reached by liberal interventions. Within this supposedly socially sensitive domain of housing interventions we can differentiate between two different types of institutional logics. One (1) is the logic of the ever more paternalising welfare benefits connected to housing-related problems, while the other (2) is the "project society" (Sampson 2002) logic of territorially focused, integrated interventions. While the former logic is the product of regime change, the latter is shaped by the Europeanisation of Hungary: the emergence of the idea of "integrated social urban rehabilitations" is tightly connected to Western European impacts and to the mainstreaming of urban policy within the EU (cf. Piattoni and Polverari 2016, 413-26). Moreover, and probably more importantly, such territorially focused and supposedly socially sensitive public investments are funded almost exclusively by the Structural Funds of the European Union. Thus when analysing the social facet of fragmented housing policies in Hungary, we should pay attention to the functional interconnection and the changing relation of these two types of logics. 
The welfare type of intervention was codified in 1993 by the new Act on Social Policy. The basic logic of this intervention-called "housing maintenance benefit" (lakásfenntartási támogatás)—was that local governments could support those families that have housing-related difficulties. The exact amount and the details of targeting were determined by local governments, but research has shown that generally these benefits did not necessarily reach either socially or spatially the poorest households (Misetics 2017; Havasi 2005, 77). Even if they reached people living in housing poverty, the amount of the benefit was extremely low (Misetics 2013). In 2004 there was a reform, and the amount of the benefit was nominally doubled (in real terms the average amount of the benefit did not change substantially between 1995 and 2014). At its peak, around 2011, more than half a million households got this benefit, but its average amount was no more than 15 EUR (Misetics 2013).

All in all, the "housing maintenance benefit" was neither a political priority, nor an effective policy tool. For example in 2009 the government spent 17.7 billion HUF on them, while they spent 10 times as much on measures supporting homeownership (Misetics 2013, 52). In sum, housing benefits followed a similar logic to welfare benefits in general after 1989. Instead of helping to ameliorate poverty and decrease polarisation that were catalysed by the liberalising reforms of the 1990s, they solidified the boundaries of a sort of "welfare prison", in which poor people are trapped and controlled by welfare institutions, instead of being helped to live in dignity (Szalai 2007). As Szalai states, a deeply divided institutional framework emerged, where on the one side there were non-supported citizens successful in the liberal market processes, and on the other side there were the needy who had fallen into the trap of the ghettoised welfare sub-system. Both socially and spatially the dualisation of society-into the well-off and poor groups-was probably slightly slowed down by benefits similar to housing maintenance benefit, but definitely not stopped. The proof of this is the emergence of segregated large-scale rural spaces (Virág 2010) and pockets of urban poverty (Ladányi 2008; Ladányi and Virág 2009) in the post-1989 period, where people live in segregation, in very bad quality buildings and without the hope of entering the world of formal labour. 
Moreover, after the landslide victory of right-wing Fidesz in 2010, resulting in the party's constitutional majority in parliament, the situation got even worse for poor people. A recently published overview of social policies in Hungary showed that since 2010-for the first time in the post-1989 history of Hungary-a coherent social vision has been carried out, which systematically contributes to the social and spatial polarisation of society (Ferge 2017). Fidesz explicitly supports the shift from welfare to workfare, which meant for example the suspension of centrally financed "housing maintenance benefits" (Misetics 2017). Now it is up to local governments whether they allocate resources for such issues or not-and it seems that this worsened the situation of those living in housing poverty (Kováts 2016). ${ }^{15}$ The criteria for allocating the benefit again is up to local governments, and may contain elements such as "a clean and orderly living environment", which results in growing dependence and exposure of the needy to the local authorities. Local politicians, street-level bureaucrats and social workers became those proxy actors, who on the one hand suffer-both professionally and personally - from austerity measures that characterise the shift from welfare to workfare, and on the other hand manage and contain the frustration of citizens trapped in poverty. Amidst a general societal crisis the housing crisis is deepening (Udvarhelyi 2014), and geographical unevenness is on the rise (Koós and Virág 2010), while the only centrally allocated housing-related benefit targeting people living in poverty was suspended.

At the same time, from the early 2000s another type of intervention into housing took shape: EU-funded territorial investments. The logic of these types of investments has been to delineate an "action area" and to concentrate various types of resources within an intensive project. The keyword for such projects is that the interventions must be "integrated". This means that various types of activities should be mixed, most notably hard and soft elements. In other words, infrastructural interventions (renovating residential buildings or flats, renewing public spaces or public buildings, building communal spaces, etc.) should be mixed with social and educational interventions (vocational training, intensive social work, supporting job finding, childcare, crime prevention, 
health-related programmes, etc.). Geographically all these interventions must be carried out in an "action area", which supposedly secures complex treatment of the complex problems identified during planning. In order to delineate an action area, it must fulfil certain statistical criteria: the segregation index should be above a certain value. Currently the segregation index is the proportion of people without a formal wage and who had undergone maximum primary education in the 15- to 59-yearold population of a given territory, and a territory counts as a "segregated area" if this index is above 35\%. According to a recent study $3 \%$ of the population of Hungary, ca. 300,000 people, live in such segregated residential areas (Koltai 2014, 52).60\% of these areas are in small settlements, the remaining $40 \%$ are in cities, but only $2 \%$ of them are in Budapest (Domokos and Herczeg 2010, 89); thus unlike in Western Europe, these segregated slums are dominantly located in rural settings.

Between 2007 and 2013 ca. 195 billion HUF (667 million EUR in 2013 prices) were jointly allocated for territorially focused interventions in Hungary, which is almost the same amount that the government spent yearly in this period on liberal housing related measures. However, this amount was divided into three main types of activities for dozens of different causes during the programming period: "function enhancing urban rehabilitation" (140 billion HUF), "social urban rehabilitation" (48 billion HUF) and "slum elimination" projects (ca. 11 billion HUF) (Koltai 2014; Terra Studió Kft. 2017). The first of these lies outside the scope of this chapter, as it focused on urban centres, without any social criteria. However, taking into account the experience of similar projects before 2007, it is very likely that these projects contributed to gentrification and displacement in urban downtowns (Nagy and Timár 2007; Somogyi et al. 2007), and thus generally they also contributed to the production of unevenness.

The second, "social urban rehabilitation" was introduced in order to prevent the negative social effects of rehabilitation-induced displacement and polarisation. Only segregated areas could be delineated as action areas, and there were dozens of projects in this period in locations where formerly no public investment took place for decades. While this could be a progressive step against uneven development, it seems that many projects were controversial in spite of their 
explicit socially sensitive framing. One type of controversy is rooted in the project logic of these interventions: local governments often suspend the management of activities after the project is closed, because their lack of commitment to the goals of projects makes them see these investments as "financially unsustainable". As the bottom line of social urban rehabilitations would be to provide complex social services and physical upgrading for mid- or long-term periods, often the rapid abandonment of activities results in the disillusionment of the residents. Another type of controversy is induced by the structural situation of local governments, who are the official beneficiaries of these projects. As in many cases they suffer from insufficient central governmental subsidies and consequently from an unsustainable fiscal situation, they try to capitalise on every incoming financial resource. This frequently means attempting to "tick the necessary boxes" needed for EU funds, and then spending the money on other types of activities than the ones which would genuinely help people in marginalised situations. There were examples of renovating churches, which were not frequently visited by the locally less well off, as "communal" infrastructure projects, instead of renovating nearby social housing units without basic amenities. A third type of controversy may be that even though the interventions help a few dozen families materially, the spillover effect of the project catalyses a process of gentrification, that in turn prices out poor people from the territory. This is what happened in one of the showcase social urban rehabilitation projects in the 8th District of Budapest (Czirfusz et al. 2015). A fourth type of controversy is connected to spatially targeting these interventions. As delineation is done by the local government, there is room to manoeuvre to decide which segregated area will benefit from the projects. Unfortunately, the selection criteria were often out of line with the social sensitivity of the tenders; in other words, the principle of targeting was not based on the needs of the residents, but on other - mainly politicalfactors. For example, in one case the selection of the action area out of ten existing segregated areas was done by the local mayor based on which of these interventions would be the most popular for the local middle classes (and result in potentially more votes in the next election). 
Thirdly, slum elimination - with a total budget of 12 billion HUFwas introduced at the end of the 2007-2013 programming period. This focused on both segregated areas and slums, but had a more crystallised philosophy. Local governments had to form a consortium with a nation-wide public institution and with an NGO in order to upgrade physically and socially the segregated slums. Instead of desegregating (i.e. demolishing the buildings and relocating the residents to "integrated" neighbourhoods) the projects aimed to keep the residents in place and provide social services locally with the continuous presence of social workers. This philosophy was criticised by various professionals and was nicknamed "beautifying the ghettos", mainly because the roots of the problems (i.e. the structural factors leading to the systematic production of marginalised territories) were not targeted, only the most basic needs of the residents (installing a place to wash their clothes and to have a shower, etc.). From another point of view, these projects also had a controlling, regulating function: many times CCTV cameras were installed, while little assistance was given to ease the burden on household budgets and similar needs. No doubt such support, though small, helped households, nevertheless, it would be hard to depict slum elimination projects as a systemic answer to the production of unevenness.

All in all, the effectiveness of the programmes that we identified as constituents of the social facet of housing intervention is at the least questionable. The logic of welfare types of benefits contributed to the institutional dualisation of Hungarian society, not to speak of the relative fiscal insignificance of such public subsidies compared to liberal interventions. Furthermore, with the recent shift from welfare to workfare, this hidden dualising effect became explicit. For example János Lázár, who is now the minister responsible for supervising all EU-funded investment activities, stated in 2011 that "who has nothing is worth nothing" (Index.hu 2011). At the same time, while the rhetoric of emerging logic-based EU-funded projects ran counter to the housing-related liberal principles of the government, their effects cannot systematically counteract the dualisation caused by all the other public interventions. Moreover, with the inflow of such transfers, the government was able to fiscally back out from the support of people affected by housing poverty. 


\section{Conclusion}

The aim of this chapter was to analyse housing-related governmental interventions in Hungary within a holistic framework. Even though since 1989 housing has been governed in a fragmented institutional environment by allocating various functions to different public and private institutions, we believe that there is a certain systematic logic behind institutional fragmentation, which results in the (re)production of socio-spatial unevenness.

Our chapter is a contribution to the recently expanding body of literature in economic geography, which aims to understand how uneven development unfolds in various ways under financial capitalism. Furthermore, it is a contribution to the political economic understanding of housing policy interventions (also strongly relating to the notion of housing financialisation). Although these conceptual approaches usually build their arguments based on empirical material from Western European and Anglo-Saxon cases, we believe it is important to balance this bias and give theoretical arguments from the position of non-core social realities. In our understanding this is an essential step to engaging with issues like regional and local development, and especially their relation to polarising tendencies in different contemporary post-crisis settings.

In Hungary, the liberal facet of housing policy receives significantly more budgetary resources than interventions in the social facet of housing policy. Since its declared aims are demographic and economic growth, it is not at all concerned with socio-spatial equity. Furthermore, while the former is a generalised, nationally implemented policy, the latter measures are often spatially localised and financially dependent on local municipalities (struggling with a constant lack of resources). Thus they are inherently uneven and are not able to do more than intervene on a small scale in situations of marginalised housing. This is similar to how general welfare instruments developed in the 1990s, which in the end had the effect of enclosing recipients in an enclave of povertyboth societally and spatially (Szalai 2007).

The liberal facet of housing policies is dominant in Hungary, with mortgage-based individual homeownership being the only form of housing tenure supported by the government. The two main policy 
instruments of this housing regime are a non-refundable government subsidy allocated according to the number of children in a family, and subsidised mortgages. Although these policies are not articulated in a spatial way and claim to generally benefit households across the whole social spectrum, we have seen that in fact they implicitly reproduce socio-spatial unevenness. Social polarisation is the result of a fundamentally credit-based housing finance system, which necessarily favours better-off households. The non-refundable housing allocation serves as a means of leveraging credit in $80 \%$ of the cases, and thus only facilitates access to further mortgage debt for a specific, selected pool of households. This_-along with the fact that housing-related subsidies for housing acquisition are managed by banks_-places a major part of the entire Hungarian housing finance system under the institutional logic of financial institutions. This logic-especially in the aftermath of the global financial crisis - is one of increased risk management, leading to more social and spatial selectivity. As a result, the uneven spatial structure of the Hungarian housing market is reinforced.

At the other end of the spectrum of housing-related interventions, the most symbolic policy instruments aiming to target poorer households are the housing maintenance benefit, which follows the logic of welfare benefits, and various tools used in integrated territorial development, which follow the logic of project society. While housing-related benefits are socially but not spatially targeted, they are delegated to local municipalities (similarly to the management of the very small remaining public housing stock), but through the lack of national-scale engagement reproduce spatial unevenness. On the other hand, territorially focused, supposedly "social" urban rehabilitation policies targeting the less well off inhabitants of social housing units are a very clearly spatially articulated set of policies. These latter policies are financed by territorial operational programmes within the national financing mechanisms for distributing European Union cohesion funds. The fact that investment in public housing practically only happens when EU funds can be used for this purpose already demonstrates the low priority of this issue in Hungarian policy-making. We do not claim that intervention in the housing situation of marginalised groups would necessarily produce further unevenness in general. But these spatially localised interventions in 
the dilapidated public housing stock do not give systemic responses to the socio-spatial inequalities produced by the dominant housing regime, and often induce further processes of marginalisation.

Altogether, there is a growing segment of Hungarian society that is not reached by either the liberal or the social facets of housing policy. As for liberal side of housing policies, many households do not fit into the stricter mortgage lending criteria put in place after the crisis or the politically preferred family model, which grants access to non-refundable subsidies. Thus, many households will not be able to access homeownership, and will have to solve their housing problems by other means. Within the social facet of housing policies, there is a tendency to continuously narrow the scope of these interventions. Local municipalities are constantly diminishing their housing stock, and-in the context of a complete lack of central government funding for these purposes-are aiming to limit all housing-related budgetary expenditures. As a result, more and more households find themselves outside the scope of housing policies-both liberal and social. They do not have access to individual, mortgage-based homeownership or to an increasingly restricted social housing stock. In this widening gap between the two ends of the currently existing housing policy, new forms of housing provision are developing, which are mostly invisible both to research and to policy. The actors driving these new forms are individual households in need of housing, and new smaller scale market actors recognising this gap.

The best response to this situation is not a new wave of excessive mortgage lending, similar to what happened before the crisis (which would attempt to push everyone into the dominant liberal housing model). Rather, new forms of affordable housing need to be developed. It is clear that publicly owned housing in its current form cannot respond to these needs. As long as local municipalities despite lacking financial resources remain the owners of public housing units, there will always be the political will not to displace the less well off and instead provide new resources for renovation (or construction) from the European Union in a timely fashion. What is needed is state intervention either in the form of state-owned social housing, developed within the framework of a national-scale programme, or in the form of providing support to create the institutional-legal and financial preconditions 
for a new institutionalised rental housing sector. These new institutions of rental housing could range from publicly regulated housing companies to self-managed housing cooperatives, and could start filling the gap between the two extremes of current, polarising housing policies.

\section{Notes}

1. Based on interviews conducted with various Hungarian urban experts.

2. We use "liberal" here in a generic sense, referring to housing policies that generally point in the direction of privatised risks and costs of housing provision, as well as a housing model based on ownership and debt. This is what Crouch (2009) calls privatised Keynesianism, or the privatisation of risk, or what Aalbers (2017) calls a general direction of housing financialisation along different trajectories. We contrast it with the idea of "social" housing policies understood in a broad sense.

3. Interview conducted with a high-ranking public official responsible for housing-related financial instruments within the Ministry of National Economy.

4. Interview conducted with a high-ranking public official responsible for housing-related financial instruments within the Ministry of National Economy; referencing internally available statistics from the Hungarian National Bank.

5. This is confirmed by interviews conducted with various real estate agents in second-tier cities (e.g. Békéscsaba, Kecskemét, Miskolc), as well as by interviews conducted with financial institutions distributing this subsidy.

6. This was a community-led project concentrating on housing issues in Bag (a town in the eastern agglomeration area of Budapest). The website of the program is available at http://bagazs.org/mit-csinalunk/hallasd-a-hangod/; and a video about the results (this is where they address the issue of CSOK) can be viewed at https://youtu.be/zaQi2_Z0a4M.

7. Interview conducted with a high-ranking public official responsible for housing-related financial instruments within the Ministry of National Economy.

8. This element of self-care is perhaps most obviously put forward in a third important housing policy instrument: the "housing savings 
contracts" (based on the German Bausparkassen model) which are constantly increasing in size and importance.

9. Interview conducted with a high-ranking public official responsible for housing-related financial instruments within the Ministry of National Economy; interview conducted with the person responsible for mortgage lending within the largest Hungarian bank; interview conducted with representatives of the Hungarian National Bank working on issues of housing finance.

10. Interviews conducted with various financial institutions involved in mortgage lending.

11. Based on interviews conducted with real estate agents in the eastern agglomeration area of Budapest, as well as in the agglomeration area of a large city in a de-industrialised region (Miskolc).

12. This claim is made based on data provided by the largest Hungarian bank about their mortgage lending, and based on data from the Hungarian National Bank about non-performing loans. However, neither of these data sets are available on a sufficiently detailed geographical scale to be able to identify very precise overlapping geographies. The most we can claim is that an institutional and spatial tendency definitely exists that supports a causal link between the geographies of financial overinclusion and exclusion.

13. We have compared these data to the number of inhabitants in the given settlement category-but this dominance of small settlements would be even stronger if we compared the data to the number of housing transactions.

14. Based on interviews conducted with a number of real estate and loan agents from the financial institutions involved in distributing this subsidy.

15. This move, that the costs of providing social services for the less well off are put on the shoulders of local governments, while the necessary financial means are not provided centrally, fits well with the more general process in post-1989 Hungary. This process was called "decentralization without subsidiarity” by András Vigvári (2008), who described how several duties were delegated to local governments in the name of autonomy, while financial autonomy was not granted for them. Although after 2010 recentralisation replaced decentralisation as the main tendency in the relation between the central and local governments, there continue to be areas that chime with what Vigvári described. 


\section{References}

Aalbers, Manuel B. 2008. "The Financialization of Home and the Mortgage Market Crisis." Competition \& Change 12 (2): 148-66. https://doi.org/10.1 179/102452908X289802.

Aalbers, Manuel B. 2017. "The Variegated Financialization of Housing." International Journal of Urban and Regional Research 41 (4): 542-54. https://doi.org/10.1111/1468-2427.12522.

Bohle, Dorothee. 2013. "Post-Socialist Housing Meets Transnational Finance:

Foreign Banks, Mortgage Lending, and the Privatization of Welfare in Hungary and Estonia." Review of International Political Economy 21 (4): 913-48. https://doi.org/10.1080/09692290.2013.801022.

Bohle, Dorothee. 2017. "Mortgaging Europe's Periphery." LSE 'Europe in Question' Discussion Paper Series. LEQS Paper No. 124. http://www. lse.ac.uk/europeanInstitute/LEQS\%20Discussion\%20Paper\%20Series/ LEQSPaper 124.pdf.

Crouch, Colin. 2009. "Privatised Keynesianism: An Unacknowledged Policy Regime." The British Journal of Politics and International Relations 11 (3): 382-99. https://doi.org/10.1111/j.1467-856X.2009.00377.x.

Czischke, Darinka. 2009. "Managing Social Rental Housing in the EU: A Comparative Study." International Journal of Housing Policy 9 (2): 121-51. https://doi.org/10.1080/14616710902920223.

Czirfusz, Márton, Vera Horváth, Csaba Jelinek, Zsuzsanna Pósfai, and Linda Szabó. 2015. "Gentrification and Rescaling Urban Governance in Budapest-Józsefváros.” Intersections 1 (4): 55-77. https://doi.org/10.17356/ ieejsp.v1i4.104.

Domokos, Veronika, and Béla Herczeg. 2010. “Terra Incognita: Magyarországi szegény- és cigánytelepek felmérése - első eredmények.” Szociológiai Szemle 20 (3): 82-99.

Dunford, Michael, and Weidong Liu. 2017. "Uneven and Combined Development." Regional Studies 51 (1): 69-85. https://doi.org/10.1080/00 343404.2016 .1262946$.

Ferge, Zsuzsa. 2017. Magyar társadalom- és szociálpolitika 1990-2015. Budapest: Osiris.

Fernandez, Rodrigo, and Manuel B. Aalbers. 2016. "Financialization and Housing: Between Globalization and Varieties of Capitalism." Competition and Change 20 (2): 71-88. https://doi.org/10.1177/1024529415623916. 
Gál, Zoltan. 2014. "Role of Financial Sector FDI in Regional Imbalances in Central and Eastern Europe." In Eurozone Enlargement: Challenges for the V4 Countries, edited by Agata Gostyńska, Paweł Tokarski, Patryk Toporowski, and Damian Wnukowski, 19-30. Warsaw: The Polish Institute of International Affairs.

Havasi, Éva. 2005. "A transzferjövedelmek szerepe a szegénység csökkentésében.” Esély 4: 66-86.

Hegedüs, József. 2006. "Lakáspolitika és a lakáspiac - a közpolitika korlátai." Esély 5: 65-100.

Hegedüs, József, and Eszter Somogyi. 2016. "Moving from an Authoritarian State System to an Authoritarian Market System. Housing Finance Milestones in Hungary between 1979 and 2014.” In Milestones in European Housing Finance, edited by Jens Lunde and Christine Whitehead, 201-17. Oxford: Wiley-Blackwell. https://doi.org/10.1002/9781118929421.ch12.

Hudson, Ray. 2016. "Rising Powers and the Drivers of Uneven Global Development." Area Development and Policy 1 (3): 279-94. https://doi.org /10.1080/23792949.2016.1227271.

Index.hu. 2011. "Lázár szerint akinek nincs semmije, az annyit is ér.” Index.hu, 19 March. http://index.hu/belfold/2011/03/19/ lazar_szerint_akinek_nincs_semmije_az_annyit_is_er/.

Koltai, Luca. 2014. Éves jelentés a lakhatási szegénységröl 2014. Budapest: Habitat for Humanity Magyarország. http://www.habitat.hu/files/ HABITAT_2014_lakhatasi_jelentes_hosszu_1109.pdf.

Koós, Bálint, and Tünde Virág. 2010. "Nyertesek és vesztesek. A magyar településhálózat polarizálódása." In A területi kutatások csomópontjai, edited by Györgyi Barta, Pál Beluszky, Zsuzsanna Földi, and Katalin Kovács, 32-54. Pécs: MTA Regionális Kutatáso Központja.

Kováts, Bence. 2016. Az önkormányzati hatáskörbe került lakhatási támogatások vizsgálata 31 önkormányzat példáján. Budapest: Habitat for Humanity Magyarország. http://www.habitat.hu/files/Onkormanyzati_lakhatasi_ tamogatasok_Habitat_0720.pdf.

Ladányi, János. 2008. Lakóhelyi Szegregáció Budapesten. Budapest: Új Mandátum Könyvkiadó.

Ladányi, János, and Tünde Virag. 2009. "A szociális és etnikai alapú lakóhelyi szegregáció változó formái Magyarországon a piacgazdasági átmenet időszakában." Kritika 7/8: 2-8. 
Misetics, Bálint. 2013. "Javaslatok egy egalitariánus lakáspolitikai reform fó irányaira: Politikai és szakpolitikai vázlat.” Esély 1: 39-73. http://www.esely. org/kiadvanyok/2013_1/misetics.pdf.

Misetics, Bálint. 2017. "Lakáspolitika és hajléktalanság." In Magyar társadalom-és szociálpolitika. 1990-2015, edited by Zsuzsa Ferge, 338-63. Budapest: Osiris.

Nagy, Erika, and Judit Timár. 2007. "A középvárosi dzsentrifikáció társadalmi hatásai a posztszocialista Magyarországon.” In A történelmi városközpontok átalakulásának társadalmi hatásai, edited by György Enyedi, 293-319. Budapest: MTA Társadalomkutató Központ.

Peck, Jamie. 2016. "Macroeconomic geographies." Area Development and Policy 1 (3): 305-22. https://doi.org/10.1080/23792949.2016.1237263.

Piattoni, Simona, and Laura Polverari, eds. 2016. Handbook on Cohesion Policy in the EU. Cheltenham: Edward Elgar.

Pósfai, Zsuzsanna, Zoltán Gál, and Erika Nagy. 2018. "Financialization and Inequalities: The Uneven Development of the Housing Market on the Eastern Periphery of Europe." In Inequality and Uneven Development in the Post-Crisis World, edited by Sebastiano Fadda and Pasquale Tridico, 167-90. Abingdon: Routledge.

Raviv, Or. 2008. "Chasing the Dragon East: Exploring the Frontiers of Western European Finance." Contemporary Politics 14 (3): 297-314. https:// doi.org/10.1080/13569770802396345.

Sampson, Steven. 2002. "Beyond Transition: Rethinking Elite Configurations in the Balkans." In Postsocialism: Ideals, Ideologies and Practices in Eurasia, edited by Chris M. Hann, 297-316. London: Routledge.

Sokol, Martin. 2013. "Towards a 'Newer' Economic Geography? Injecting Finance and Financialisation into Economic Geographies." Cambridge Journal of Regions, Economy and Society 6 (3): 501-15. https://doi. org/10.1093/cjres/rst022.

Somogyi, Eszter, Hanna Szemzö, and Iván Tosics. 2007. "Városrehabilitáció kétszintü önkormányzati rendszerben: budapesti sikerek és problémák. 1994-2006." In A történelmi városközpontok átalakulásának társadalmi hatásai, edited by György Enyedi, 69-92. Budapest: MTA Társadalomkutató Központ.

Szalai, Júlia. 2007. Nincs két ország...? Budapest: Osiris.

Terra Studió Kft. 2017. "Integrált városfejlesztések értékelése. Ex-post értékelés a 2007-13-as időszakról.” https://www.palyazat.gov.hu/download. php?objectId=71199. 
Udvarhelyi, Éva Tessza. 2014. "'If We Don't Push Homeless People Out, We Will End Up Being Pushed Out by Them': The Criminalization of Homelessness as State Strategy in Hungary." Antipode 46 (3): 816-34. https://doi.org/10.1111/anti.12068.

Vigvári, András. 2008. "Szubszidiaritás nélküli decentralizáció: Néhány adalék az önkormányzati rendszer magyar modelljének korszerűsítéséhez." Tér És Társadalom 22 (1): 141-67.

Virág, Tünde. 2010. Kirekesztve. Akadémiai Kiadó: Falusi gettók azország peremén. Budapest.

Open Access This chapter is licensed under the terms of the Creative Commons Attribution 4.0 International License (http://creativecommons. org/licenses/by/4.0/), which permits use, sharing, adaptation, distribution and reproduction in any medium or format, as long as you give appropriate credit to the original author(s) and the source, provide a link to the Creative Commons license and indicate if changes were made.

The images or other third party material in this chapter are included in the chapter's Creative Commons license, unless indicated otherwise in a credit line to the material. If material is not included in the chapter's Creative Commons license and your intended use is not permitted by statutory regulation or exceeds the permitted use, you will need to obtain permission directly from the copyright holder.

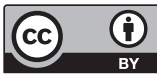

